\title{
KEYNESIAN AND SCHUMPETERIAN EFFICIENCY IN A BOP-CONSTRAINED GROWTH MODEL
}

\author{
Eva Catela* \\ Gabriel Porcile**
}

\begin{abstract}
The paper aims to contribute to the debate on specialization and growth in two forms. Firstly, it develops a North-South model in which the ratio between the income elasticity of exports and imports in the South (that gives the rate of growth compatible with external equilibrium) depends on the Keynesian and Schumpeterian efficiency of the pattern of specialization, as defined by Dosi et al (1990). The model draws on key insights of the technology gap literature to discuss how these efficiencies are related to the dynamics of technological learning. Secondly, the model is tested including the variables Keynesian and Schumpeterian efficiency in a Keynesian growth regression. Several estimation procedures are used to test the model, among which Finite Mixture Estimation, which allows for estimating the parameters for homogenous groups of countries.
\end{abstract}

Key-Words: Schumpeterian efficiency, Keynesian efficiency, Balance-of-Paymentsconstrained growth, Thirlwall's Law.

JEL Codes: 0 11, 033

\footnotetext{
* Department of Economics - Federal University of Santa Catarina.

** Department of Economics - Federal University of Paraná and CNPq.
} 


\section{Introduction}

The role of specialization in economic growth has been the subject of an enduring debate among economists of diverse schools of thoughts. The idea that the quality of exports matters is a central tenet in both the Latin American structuralist tradition ${ }^{1}$ and in the Keynesian-Shumpeterian (KS) approach to economic growth. These schools suggest that international competitiveness and exports play a key role in sustaining the expansion of the economy with external equilibrium (a point stressed as well by Kaldor, 1978, chapter 4). Inversely, in the neoclassical tradition the specific pattern of specialization is not relevant since it assumes that trade would suffice to evenly spread productivity gains around the world. This view has changed in recent years and some authors of neoclassical persuasion have begun to accept that the quality of exports could help to explain why growth rates differ ${ }^{2}$.

This paper aims at contributing to the KS literature in two ways. The first one (Section 1) is by presenting a North-South model which formalizes the interrelations between specialization and growth. There are many forms in which this interrelation can be modeled. We will focus on the relationship that exists between specialization and the income elasticity of the demand for exports and imports (the elasticity ratio). Following Thirlwall (1979) and McCombie and Thirlwall (1994), we argue that in the long run the relative rate of growth of a certain country (as compared to the rate of growth of the world economy) should equal this ratio. In addition, following Dosi et al. (1990) and Cimoli et al (2009), we will argue that the elasticity ratio is a function of the "Schumpeterian Efficiency" $(K)$ and "Keynesian Efficiency" $(S)$ of the pattern of specialization. The model allows $K$ and $S$ to interact though time so as to endogenously produce different trajectories of growth and catching up in the international economy.

The second contribution (Section 2) is to present an empirical test of the suggested model for the period 1985-2007, based on a large sample of countries and using different econometric techniques. More specifically, we use four estimation procedures: pooling OLS, Panel Data with Fixed Effects, Panel Data with Random Effects and Finite Mixture Models. The latter - which has not yet been used to test growth models - is particularly interesting since allows for identifying differences between the parameters of different groups of countries. Such groups are endogenously constructed, 
on the basis of the statistical analysis of their heterogeneity, not through the imposition of exogenous criteria. In all cases we test the idea that specialization affects growth by including $K$ and $S$ along with the variables traditionally considered in Balance-ofPayments-constrained growth models ${ }^{3}$, namely the terms of trade and the rate of growth of world income.

\section{The Model: A KS View on Convergence and Structural Change}

a) Keynesian and Schumpeterian efficiency and the elasticity ratio

Our point of departure is the canonical Balance-of-Payments-constrained growth model. One country (a small open economy) will be called "South" and the rest of the world will be called "North". The key result of the model is that under certain assumptions (see bellow) the long run rate of growth is given by the ratio between the income elasticity of the demand for exports and imports, which is known as Thirlwall's Law ${ }^{4}$. Formally:

(1) $y^{*}=\frac{(1+\eta+\mu)\left(p-p^{*}-n\right)+\varepsilon z}{\pi}$

In equation (1) $y^{*}$ is the Southern long run rate of growth compatible with BOPequilibrium, $p$ is domestic inflation, $p^{*}$ is international inflation, $n$ is the rate of growth of the nominal exchange rate (defined as units of local currency per dollar), $z$ is the rate of growth of the world economy (North), $\eta$ and $\mu$ are negative price elasticities of North and South exports, respectively, and $\varepsilon$ and $\pi$ are positive income elasticities of North and South imports, respectively. There are no capital flows in the model, which implies that in the long run the South cannot grow based on external debt ${ }^{5}$.

Assuming that the real exchange rate remains constant $\left(p-p^{*}-n=0\right.$, in accordance with the dynamic version of the principle of purchasing power parity, PPP), equation (1) becomes:

(2) $y^{*}=\frac{\varepsilon}{\pi} z=\xi z$ 
(3) $\frac{y^{*}}{z}=\xi$

This represents the simplest BOP-constrained growth model relating growth to the income elasticity ratio, defined as $\xi \equiv \varepsilon / \pi$. Despite of its simplicity, the model provides useful insights. In particular, for having sustainable convergence in the long run, $\xi$ should be higher than the unity: this would make possible that the South can grow at higher rates than the North without compromising external equilibrium ${ }^{6}$.

The crucial aspect to be addressed from a theoretical point of view is what forces affect the evolution of the income elasticity ratio $\xi$. For the sake of simplicity, we assume that the income elasticity of the demand for imports in the South $(\pi)$ is constant and then focus on that of exports $(\varepsilon)$. We will argue that it depends on what Dosi et al (1990) has called the Keynesian and Schumpeterian efficiencies of the specialization pattern. The concept of Keynesian efficiency $(K)$ captures direct demand-side effects of export growth and is represented by the share in total exports of sectors whose international demand grows at higher rates than the world average. A country may have a high $K$ because of its past achievements in technological competitiveness, because of active pro-export policies, preferential trade agreements and/or just because it has good luck in the commodity lottery ${ }^{7}$.

The concept of Schumpeterian efficiency $(S)$, in turn, captures the ability of each country to dynamically adjust to the evolution of demand and technology, as well as to sequentially move towards sectors in which demand grows faster. This ability is a function of the country's technological capabilities, represented by the share of technology-intensive sectors in the export structure. Such capabilities provide the long run basis for creating new markets and sustain international competitiveness as new goods, new processes and new actors continuously challenge the prevailing distribution of market shares, as Schumpeter convincingly argued in his classical work (Schumpeter, 1952, chapter 9). To remain competitive in the domestic and international markets the country must be able to innovate, learn and adopt new technology faster than its competitors. In addition, Schumpeterian efficiency allows the country to more easily overcome supply-side constraints as the economy grows. This would be important in 
periods in which the economy is very close to full employment or in which certain specific factors (such as qualified labor or specialized machinery) are scarce. In conventional models the supply constraint is the general case, as they assume the validity of Say's Law. We take the opposite view, in which the influence of the supply depends on its effects on effective demand. This excludes the automatic adjustment mechanisms between supply and demand implicit in Say’s Law.

The relationship between export growth, $K$ and $S$ can be expressed in a formal way as follows:

(4) $y^{*}=\frac{(1+\eta+\mu)\left(p-p^{*}-n\right)}{\pi}+\frac{\alpha}{\pi} K+\frac{\beta}{\pi} S+\frac{\psi}{\pi} z$

In equations (4), $K$ is the share in total exports of sectors which are dynamic from a demand-side point of view, and $S$ is the share in total exports of sectors which are dynamic from a technological point of view. The positive parameters $\alpha$ and $\beta$ give the effect of $K$ and $S$, respectively, on the rate of growth of exports, while the positive parameter $\psi$ captures other influences. The variables $K$ and $S$ are natural logarithms. If PPP holds (i.e. $p-p^{*}-n=0$ ) we get:

(5) $y^{*}=\frac{\alpha}{\pi} K+\frac{\beta}{\pi} S+\frac{\psi}{\pi} z$

It is important to stress that a country with high $K$ may not be able to sustain growth in the long run if it does not have $S$, which provides the technological capabilities necessary for adaptation and innovation. If competitiveness is solely based on natural resources or cheap labor, sooner or later the country will loose ground in the international markets. This is a pattern clearly identified by economic historians and by the recent experience of several Latin American countries ${ }^{8}$.

On the other hand, a country which solely focuses on technology may experience high productivity growth in some sectors, but if this is not matched by a parallel increase in effective demand, the result will be higher unemployment and inequality rather than higher growth. Learning must be aimed at seizing a higher share of international 
effective demand if the objective is to foster economic growth - the basic principle of Keynesian growth models. We acknowledged the possibility of having supply-side constraints in some countries and periods, in which case technology directly feeds economic growth. Still, as mentioned, we in general see that the effects of technology on growth as mediated by its effects on effective demand (in this case, in the rate of growth of exports).

In sum, from a long term perspective, export growth depends on the various forces that shape access to the international market, related to pro-export policies, favorable or unfavorable demand shocks and institutions, along with the technological capabilities necessary to transform the specialization pattern, avoid falling behind the international technological frontier and remain competitive in the most dynamic markets.

\section{b) The dynamics of specialization and growth}

b.1) The dynamics of $S$

We will now focus on the dynamics of $K$ and $S$, drawing from the Schumpeterian literature. The analysis of the dynamics of growth is central to discuss convergence and divergence, and for understanding the formation of relatively homogenous groups of countries in the international economy.

First, we model the participation of high-technology sectors in the export structure as a function of leads and lags in the international innovation and diffusion of technology. We express these leads and lags in terms of the technology gap, $G=\ln \left(T_{N} / T_{S}\right)$, the ratio between the technological capabilities of the South $\left(T_{S}\right)$ and that of the North $\left(T_{N}\right)$.Our key hypothesis is that the share of high-technology sectors in the export structure is a function of the technology gap ${ }^{9}$. Formally:

(6) $S=\rho-\tau G$

Since this is a North -South model in which the North is the technological leader, it will be true that $1<G$. Clearly, if the technology gap is completely eliminated, then $G=1$ 
and $S=\rho-\tau$. Thus, $\rho-\tau>0$ represents the international distribution of high-tech exports in the absence of technological asymmetries. Differentiating (6) with respect to time renders:

(7) $\dot{S}=-\tau \dot{G}$

In other words, learning drives $S$. It is therefore necessary to look in more detail at the evolution of $G$. Fagerberg $(1988,1994)$ and Narula (2004) suggest that the initial level of the gap is important for the dynamics of $G$, but it is not clear whether it has a positive or a negative effect. From one hand, a high technology gap is an opportunity for imitation and in this sense it boosts the potential rate of technical change in the South. On the other hand, if the technology gap is too high, the South would not have the minimum capabilities required to learn and effectively become an imitator ${ }^{10}$. In this paper we will assume that the influence of the technology gap on the rate of growth of the gap is negative, i.e. the gap mainly represents an opportunity for the South to learn from the leader. Therefore, the higher the North-South gap, the higher will be the rate of learning of the South as compared to that of the North (later we discuss what happens when the level of the gap has a negative effect on Southern learning). In any case, it should be observed that there is nothing automatic in learning, whose rate will depend on the developing country's own efforts to absorb foreign technology. The technology gap may represent an opportunity, but it can only be exploited in the presence of active policies and costly investments in the South.

A second variable affecting the evolution of the technology gap is the Keynesian efficiency of the specialization pattern. Following the Kaldorian tradition, we assume that there exists increasing returns to economic growth and in particular from export growth. Higher Keynesian efficiency favors the process of catching up by heightening investment (with its related components of embodied and disembodied technology) and the various forms of learning that accompanies economic growth, such as learning by doing, learning by using and learning by exporting (see Rosenberg, 1982; Lundvall, 1992). Formally:

(8) $\dot{G}=\gamma-\lambda G-v K$ 
The parameters $\gamma$ (the autonomous component in the evolution of the technology gap ${ }^{11}$ ) and $\lambda$ (which captures the intensity of technological spillovers from North to South) ${ }^{12}$ and $v$ (which captures the learning effects of growth) are all positive. In a very concise form, their values depend on the characteristics of the National System of Innovation, i.e. the general framework that shapes in each country the stimulus for learning and investing in technology, R\&D and education ${ }^{13}$. Countries differ widely in terms of their NSI and this leads to large differences in their efforts for catching up with the international technological frontier.

Using (8) and in (7) renders:

(9) $\dot{S}=\tau(-\gamma+\lambda G+v K)$

And using (6) in (9):

(10) $\dot{S}=\tau\left(-\gamma+\frac{\lambda}{\tau}(\rho-S)+v K\right)$

b.2) The dynamics of $\mathrm{K}$

We have argued that changes in $K$ depend positively on $S$. In other words, technological capabilities allow the country to innovate, adapt and move towards rapidly growing sectors in the international economy ${ }^{14}$. Yet we will assume that this effect is not linear. After a critical value of the share of high-tech sectors in total exports, the ability of the country to conquer new fast-growing markets increases at a decreasing rate. This is a reasonable assumption that skews the possibility of an explosive behavior in competitiveness and rates of growth. It is also reasonable to expect that it will become more difficult to seize new markets when the country already controls a large share of world demand. Formally:

(11) $\dot{K}=S(\phi-S)$ 
The parameter $\phi$ captures the influence of technological capabilities on the ability to compete and get a higher share of the international effective demand through time. This parameter thus expresses in a very concise form the key inter-relation that exists between supply-side and demand-side conditions, mediated by international competitiveness and export growth.

Equations (10) and (11) form a system of differential equations which endogenously produce two equilibrium positions defined by:

(12) $S_{1}^{*}=0, K_{1}^{*}=\frac{\gamma \tau-\lambda \rho}{v \tau}$

(13) $S_{2} *=\phi, K_{2}^{*}=\frac{\gamma \tau+\lambda(\phi-\rho)}{\nu \tau}$

The Jacobian of the dynamic system in equilibrium is as follows:

(14) $\mathbf{J}=\left[\begin{array}{cc}-\lambda & v \tau \\ \phi-2 S * & 0\end{array}\right]$

It is straightforward that the trace is negative $(-\lambda)$, while the sign of the determinant $(-(\phi-2 S *) v \tau)$ depends on the value of $S^{*}$. The first equilibrium value of Schumpeterian efficiency $\left(S^{*}{ }_{1}=0\right)$, given by equation $(12)$, produces a negative determinant and therefore a saddle point (unstable except for the too specific set of initial values that defines the stable branch). On the other hand, the second equilibrium value (at $S^{*}{ }_{2}=\phi$ ), given by equation (13), renders a positive determinant $(\phi \nu \tau)$ and hence a locally stable system.

The path from an initial position $\mathrm{X}$ towards the stable equilibrium $\mathrm{E}$ is depicted in Figure 1. This figure also presents an exercise in comparative dynamics in which changes in the structural parameters of the model modify the elasticity ratio and the equilibrium rate of growth $y^{*}$. Assume, for instance, that a certain country strengthens its capacity to transform technological capabilities into effective demand and export growth (for instance, by encouraging innovative firms to export though tax rebates or 
financing), thereby raising $\phi$. As a result of the new policy the isocline $\dot{S}=0$ shifts to the right and the equilibrium value of $S$ increases from $S_{2} *$ to $S_{2} * *$ (we do not consider the unstable solution represented by $S^{*}{ }_{1}=0$ ). This in turn gives rise to an increase in $K$ in equilibrium from $K_{2} *$ to $K_{2} * *$ (see figure 1A). To the extent that both $K$ and $S$ are higher in the new equilibrium, then the rate of growth of exports increases too (equation 4).

From equation (4) and (5) it is straightforward that the economy will be able to grow at higher rates with external equilibrium after the adoption of the new policy. Figure 1B shows the level curves representing different combinations of $K$ and $S$ that produce a constant growth rate in equilibrium. The shift in policy leads the economy to a higher level curve, from $y^{*}$ to $y^{* *}$. This happens because increases in $\phi$ foster demand growth and trigger the Kaldorian forces related to learning and the strengthening of technological capabilities. At the end of the day the change in $\phi$ produced a favorable transformation of the pattern of specialization in terms of both $S$ and $K$.

\section{[ Figure 1 here ]}

Another interesting point is what happens when the country lacks the minimum technological capabilities required for catching up and hence $\lambda$ is negative. In this case, the higher the technology gap, the higher will be the rate at which the country falls behind the international technological frontier (equation 8). The Jacobian (14) shows that the trace is positive and therefore the system is unstable. Not only the rates of growth would differ across countries, but such differences would increase through time, heightening the asymmetries between North and South in the international economy.

In sum, the suggested KS model suggest that the technology gap and the pattern of specialization are endogenously determined and drive export growth, which in turn defines the rate of economic growth through Thirlwall's Law. In the next section, we will test empirically this hypothesis based on different estimation procedure, working with a data base comprising a large sample of countries for the period 1985-2007. 


\section{Growth and Specialization: Empirical Analysis}

We now address empirically the relationship between specialization and growth, testing equation (4) -- in which growth is a function of $K$ and $S$, along with the growth of the world economy and changes in the terms of trade. Firstly, we use conventional Panel Data estimation procedures (Fixed Effects and Random Effects). Secondly, we use the Finite Mixture methodology, which allows for endogenously identifying groups of countries and estimating different parameters for these groups ${ }^{15}$. A conventional Pooling estimation is included with comparative purposes, although it clearly has many disadvantages respecting the other procedures (Arellano, 2003; Wooldrich, 2002)

\section{a) Panel Data estimations}

The estimated equation is a follows:

(15) $y_{i}=\beta_{0}+\tilde{\alpha}\left(K_{i}\right)+\widetilde{\beta}\left(S_{i}\right)+\tilde{\psi}(z)+\tilde{\mu}(t o t)_{i}+e_{i}$

where $\tilde{\alpha}=\alpha / \pi, \tilde{\beta}=\beta / \pi, \tilde{\psi}=\psi / \pi$ and $\tilde{\mu}=(1+\eta+\mu) / \pi$ and $e_{i}$ is a white noise error term . Variables $K$ and $S$ are taken in natural logarithms.

This equation opens the black box of the elasticity ratio to make it a function of $K$ and $S$. The variables $y$ and $z$ are the real rates of GDP growth of country $i$ and the world economy, respectively; $S_{i}$ is the share of high-tech sectors in total exports (Schumpeterian efficiency) and $K_{i}$ is the share of sectors whose demand grew at higher rates than the average demand growth in the world economy (Keynesian efficiency) in the considered period (1985-2007). The validity of Purchasing Power Parity is an empirical matter which requires to be tested by including the terms of trade (tot) in the estimated equation ${ }^{16}$. In addition, the rate of growth of the world economy is included with a view to capturing (through the parameter $\tilde{\psi}$ ) other factors that could affect the elasticity ratio but which are not related to the Schumpeterian and Keynesian efficiencies. 
In a first exercise, three estimation procedures were applied (Pooled OLS, Least Square Dummy Variables - Fixed Effects and Random Effects) whose results are presented in Table 1.

[ Table 1 here ]

The results are compatible with the hypothesis that the pattern of specialization affects growth through its two dimensions (Schumpeterian and Keynesian). The variable coefficients are all positive as expected and significant at the $1 \%$ level. In addition, it can be seen the technological dimension of international competitiveness has a stronger leverage on growth than pure demand shocks. Another point that deserves attention is that the coefficient of the variable $z$ (rate of growth of the world economy) is relatively high and significant, suggesting that the variables $S$ and $K$ cannot fully capture all the complex set of variables influencing the elasticity ratio. Last but not least, the variable terms of trade is significant and has the expected signal (which is negative, suggesting that the Marshall-Lerner condition is valid).

As regards the estimation procedures, the Hausman test indicates that the Fixed-Effects model is more adequate than the Random Effect one. The $\chi^{2}$ statistics $(57,79)$ allows for rejecting the idea that differences in fixed coefficients are unsystematic.

The results in Table 1 correspond to the whole period 1985-2007. Still, we are interested in looking at how $S$ and $K$ behave in different periods. In particular, in the Latin America case, there have been several changes in economic policy and very different contexts in terms of inflation and the real exchange rate, which significant implications for the pattern of specialization (ECLAC, 2007). The eighties were years of high inflation, while the nineties were characterized by low inflation and overvalued domestic currencies, compromising the competitiveness of several industrial activities (Stalling and Peres, 2000). Moreover, in the eighties the external debt posed a severe burden on many developing countries (in Latin America, Asia and some of the socialist economies of Eastern Europe), which became net exporters of capital. The efforts to promote exports in the eighties sought to generate a net surplus in the trade balance, which was then used to pay the interests of the external debt rather than to encourage growth. Inversely, in the nineties foreign lending was resumed in the international 
markets and this facilitated growth (ECLAC, 2001). Such changes in the international financial conditions strongly affected the link between exports, growth and the Balanceof-Payments constraint.

Table 2 presents the results of the estimations for four periods: 1985-90, 1991-1995, 1996-2000, 2001-2007. We applied both Fixed Effects and Random Effects, but the Hausman Test indicates that the former model is more adequate. Therefore Table 2 only presents the outcomes of the Fixed Effects model.

\section{[ Table 2 here ]}

Three aspects emerge from Table 2. First, the sign of the coefficient of $K$ is negative in the eighties, contrary to what could have been expected. Subsequently it becomes positive, in conformity with the models's prediction. Why does this variable have the "wrong" signal in the eighties? A tentative answer should take into account the abovementioned exceptional conditions of this period (characterized by extremely high levels of external debt in several developing economies, particularly in Latin America), leading to large fluctuations in the real exchange rate and in international competitiveness. Secondly, the value of the $S$ coefficient is much larger than that of $K$ except in the 1996-200 period, in which it is slightly lower. This confirms the results obtained in the first set of estimations as regards the role of technological capabilities as a condition for a country to fully benefit from the expansion the international effective demand.

In sum, the econometric results are compatible with the predictions of the KS school in growth theory, in which the pattern of specialization matters for long run growth. The evidence suggests that the Keynesian and Schumpeterian dimensions are both relevant for defining the rates of growth within the framework of a BOP-constrained growth model.

\section{b) Finite Mixture Procedure}

Along with Panel Data techniques, we tested the model using a Finite Mixture procedure. This procedure has not yet been used in the literature to test growth models. 
However, it has some very interesting properties as allows for controlling the heterogeneity of the data. In effect, if the data is generated from a density function with finite mixtures, in which different groups show different parameters, then estimations based on the hypothesis of a simple probability density function produce biased estimates (Frühwirth-Schnatter, 2006). For this reason it is preferably to model the statistical distribution assuming that there exists a mixture or combination of distributions. A finite mixture may be a way of modeling the data in a more flexible form, with each mixture component providing a local approximation to some part of the true distribution.

The regression model with finite mixtures can be written as:

(16) $y_{i j}=\alpha_{j}+\beta_{1 j} K_{i j t}+\beta_{2 j} s_{i j t}+\beta_{3 j} Z_{i j t}+\beta_{4 j} t o t_{i j t}+\beta_{5 j} y_{t-1 i j t}+u_{i j t}$ $i=1,2, \ldots ., \mathrm{n} ; j=1,2, \ldots, \mathrm{J} ; \mathrm{t}=1985, \ldots, 2007$.

$\alpha_{j}$ is the intercept for component $j, y_{i j t}$ is the endogenous variable for country $i$ in component $j$, in year t (GDP per capita growth rate), $S_{i j t}$ is the share of high-tech sectors in total exports for country $i$ in component $j$, in year $\mathrm{t} ; K_{i j t}$ is the share of sectors whose demand grew at higher rates than the average demand growth in the world economy for country $i$ in component $j$, in year $\mathrm{t}$; tot $_{i j t}$ are the terms of trade for country $i$ in component $j$, in year $\mathrm{t}, z_{j t}$ are the rate of growth of the world economy for component $j$, in year t. $\quad y_{t-1 i j t}$ is the lagged dependent variable. We include the lagged dependent variable because it absorbs the time-invariant properties, capturing the fixed effects. Finally, $u_{i j}$ is the error term, whose variance $\sigma_{i j}^{2}$ is assumed to be normal and homocedastic within components, but probably heterocedastic between components ${ }^{17}$.

We used the Finite Mixture Model (FMM) to estimate the parameters for the variables of our growth model ( $K$ and $S$ ) without having to arbitrarily separate countries in different groups. The finite mixture models are estimated using maximum likelihood, while cluster-corrected robust standard errors are used throughout for inference purposes. These are implemented by the Stata package fmm (Deb, 2008). 
The estimation procedure requires, firstly, identifying the number of groups that best suits the heterogeneity of the data. The dependent variable for group formation is the GDP per capita. Table 3 presents two statistics that measure the quality of adjustment, computed with a view to deciding whether the estimation should be done with just one component (which corresponds to OLS), two or three components (to be estimated by means of the FMM). The statistics used to choose the appropriate model are the Akaike Information Criterion (AIC) and the Bayesian Information Criterion (BIC) ${ }^{18}$.

\section{[ Table 3 here ]}

It should be recalled that the lower the AIC and BIC indexes, the better is the adjustment of the model. Both statistics clearly point out that the best model is FMM with three components. Another form of testing the number of groups that should be included in the estimation procedure is through the LM statistic. If the $f_{y}$ function takes the form of a density mixture for all $\mathbf{y} \in y$, then:

(17) $f_{y}=\eta_{1} f_{1}(y)+\ldots+\eta_{j} f_{j}(y)$

In this equation $f_{j}(y)$ is a density probability function for all $j=1, \ldots, \mathrm{J}$. The density $f_{j}(y)$ is called "component density", where $\mathbf{J}$ is the number of components. The parameters $\eta_{1}, \ldots, \eta_{j}$ are weights, whose distributions are given by the vector $\eta=\left(\eta_{1}, \ldots, \eta_{j}\right)$. The null hypothesis is that the $f_{Y}$ has two components as against the alternative of having three components. A $\chi^{2}$ test provides a significant statistic $\left(\chi^{2}=\right.$ $116,87)$, allowing us to conclude in favor of the model with three components.

\section{[ Table 4 here ]}

Table 4 shows the results of group formation based on FMM. Group 1, which has the lowest income per capita, represents about $45 \%$ of the countries of the sample, while Group 3, with the highest income per capita, represents about $13 \%$. The middle-income Group 2, which includes all the Latin American countries, responds for about $41 \%$ of the countries. These groups are endogenously formed by the statistical analysis of the 
sample variance. The countries included in each group are listed in Table A2 (see the statistical appendix at the end of the paper).

A few points are worthwhile stressing. First, all the Latin American countries are in Group 2 and none of them migrated to a different group. Chile managed to move from the middle to the top position within Group 2, while Bolivia and Nicaragua moved towards the lower end -- with Bolivia in a transitional position between Groups 2 and 1. But all they remained in the same group. Inversely, there is strong inter-group mobility in the case of Asia and some European economies. In effect, Indonesia and China moved from Group 1 to Group 2 in 1992 and 1998-99, respectively. Korea, in turn, migrated from Group 2 to Group 3. In Europe, Ireland and Spain moved from Group 2 to Group 3 in 1995-96, and so did Greece and Portugal by the end of the period. Last but not least, poor countries in Group 1 were unable to improve their position and escape towards a higher Group. Most African countries and a significant number of Asian ones are in this highly unfavorable condition, which seems to represent a kind of under-development trap (table A2).

In terms of the model presented in the previous section, these results suggest that some countries succeed in changing the value of the parameter $\phi$ that defines the equilibrium levels of $S$ and $K$. These countries therefore were able to catching up and join the group of the more advanced economies, as represented by the shift to the right of the $\dot{S}=0$ locus in Figure 1A.

After forming the groups, the next step is to run a FMM regression for the growth model, whose results are presented in Table 5.

\section{[ Table 5 here ]}

Some of the conclusions that can be drawn from Table 5 are the following:

i) The coefficients obtained using FMM are higher than those obtained with the other estimation procedures (including fixed effects). All groups show 
positive and significant coefficients for the variables $S$ and $K$. Schumpeterian efficiency in all cases has a larger impact on growth than the Keynesian one.

ii) The coefficient of Schumpeterian efficiency for Groups 1 and 2 are higher than for Group 3. Efforts for export diversification towards more technologically intensive sectors can be expected to have a larger impact on growth in developing economies. As predicted by the structuralist tradition, structural change plays a crucial role in these economies.

iii) The terms of trade show the expected negative signal associated with the Marshall-Lerner condition, except for the high-income economies (Group 3), where the coefficient does not significantly differ from zero. This may be explained by the fact that the advanced economies compete in high-tech sectors where innovation is more important than price competitiveness.

iv) The lagged variable is higher in Group 3 and 2 than in Group 1, suggesting that growth shows a lower persistence in the last Group. This may imply higher growth volatility in the least advanced countries, stemming from fewer linkages and a stronger influence of the commodity lottery and exogenous demand shocks.

v) Concurrently, growth persistence is higher in Group 3 than in Group 2. Another form of looking at this result is to suggest that the higher the technological capabilities of the country, the higher the intensity of the Kaldor-Verdoor forces of increasing returns that sustain growth through time.

The FMM methodology confirms the results arising from previous estimations respecting the significance and signal of the variables of the model. Still, the FMM procedure has a critical advantage, namely it allows for obtaining specific coefficients for each group, capturing in a more precise form the influence of the countries' productive structures on growth. Differences in the coefficients across groups can be interpreted in terms of the different levels of technological and productive development that each region has achieved.

It is worthwhile stressing that estimating the parameters for endogenous groups of countries cannot be equated with the formation of convergence clubs, as suggested in neoclassical convergence theory (Quah, 1996). Our model is based on a KS perspective 
in which each country has its own long run rate of growth and there is no reason for the poor countries to catch up with the rich countries. We expect in equilibrium different patterns of specialization and persistent technological asymmetries. The model does not consider the possibility of decreasing returns to capital accumulation. Convergence is possible on the basis of international technological diffusion and spillovers, along with industrial policies that strengthen the NSI and international competitiveness.

In sum, The FMM procedure allows for both constructing an endogenous typology of countries in the international economy and for identifying movements within and between groups. Some countries changed groups and succeed in getting closer to the technological leaders, while others remained trapped in a low-growth vicious cycle. The FMM methodology helps to identify these movements and highlights differences in the coefficient values of the model related to technology and specialization. The laggard economies seem to be more responsive to shifts in the pattern of specialization towards more technological intensive sectors. A low-tech industrial structure hampers the positive effects arising from exports and the Harrod-Thirlwall foreign trade multiplier.

\section{Concluding Remarks}

This paper sought to contribute to the Keynesian-Schumpeterian literature on economic growth in two forms. Firstly, by developing a North-South model which makes explicit how the Keynesian $(K)$ and Schumpeterian $(S)$ efficiencies of the specialization pattern interact, shaping the rate of growth of exports - and therefore the BOP-constrained rate of growth. A dynamic insertion in the international economy at a certain moment does not guarantees long run growth if the country lacks the technological capabilities necessary to respond and adjust to changing technologies and markets. Conversely, technological capabilities favor growth only if they allow the country to capture a larger share of the international effective demand. The model formalizes this interaction and relates it to the technology gap.

Secondly, the hypothesis that specialization matters (in the form of the $K$ and $S$ ) is tested using different estimation procedures in a sample of 107 countries for the 19852007 period. These procedures included conventional Panel Data estimation (Random and Fixed Effects) and the Finite Mixture Model, in which different groups of countries 
are formed based on the heterogeneity of the sample. The results obtained though the different estimation procedures do not contradict the idea that specialization matters and confirm in general the predictions of the Keynesian-Schumpeterian approach. The coefficients of $K$ and $S$ capture the interaction between supply side and demand-side variables in which learning affects growth by redefining income elasticities and the BOP constraint.

In addition, the use of FMM allows for identifying relevant differences in the coefficients of the groups of countries. In particular, they suggest that the poorest countries have major difficulties in transforming the stimulus of exports into economic growth. The problem of growth is compounded in these economies by a poorly diversified, low-tech productive structure. In this sense, our results suggest that the old structuralist concern with the specific form in which countries integrate to the world economy seems thoroughly justified. In particular, policies aimed at encouraging exports should be complemented by industrial and technology policies fostering structural change in favor of technology-intensive sectors.

\section{Bibliography}

Albuquerque, E.M. (2007) "Inadequacy of Technology and Innovation Systems in the Periphery", Cambridge Journal of Economics, 31 (5), pp. 669-690.

Alonso, J.A. and Garcimartín, C. (1998-99) "A New Approach to Balance-of-Payments Constraint: Some Empirical Evidence”, Journal of Post Keynesian Economics, $21(2)$.

Amable, B. (2000) "International Specialization and Growth", Structural Change and Economic Dynamics, 11(1), 413-431.

Araujo, A. e Lima, G.T. (2007) "A Structural Economic Dynamics Approach to Balance-of-Payments-Constrained Growth", Cambridge Journal of Economics, 31 (5). 755-774.

Arellano, M. (2003) Panel Data Econometrics, New York: Oxford University Press.

Akaike, H. (1973) "Information Theory and an Extension of the Maximum Likelihood Principle” In: B.N. Petrov e F. Csaki (Eds.), Second international symposium on information theory.

Bell, M. and K. Pavitt (1993), "Technological Accumulation and Industrial Growth: Contrasts Between Developed and Developing Countries", Industrial and Corporate Change 2(1), 157-210.

Bértola, L. and Porcile, G. (2006) "Convergence, Trade and Industrial Policy: Argentina, Brazil and Uruguay in the International Economy, 1900-1980. 
Revista de Historia Económica - Journal of Iberian and Latin American Economic History, XXIV, p.120 - 150.

Bértola, L., Higachi, H. and Porcile, G. (2002) "Balance-of-Payments-Constrained Growth in Brazil: a Test of Thirlwall's Law, 1890-1973", Journal of Post Keynesian Economics, Vol. 25, No. 1, 123-140.

Capdevielle, M. (2005) "Globalización, Especialización y Cambio Estructural en América Latina", in Cimoli, M (ed), Heterogeneidad Estructural, asimetrías Tecnológicas y Crecimiento en América Latina. Santiago: BID-CEPAL.

Castellacci, F. (2002) "Technology Gap and Cumulative Growth: Models and Outcomes", International Review of Applied Economics 16 (3), 333-346.

Cimoli and Porcile (2007) "Specialization, Wage Bargaining and Technology in a Multigoods Growth Model", paper presented to the Congress on the Institutional and Social Dynamics of Growth and Distribution, Lucca, December.

Cimoli, M. and Porcile, G. (2009) "Sources of Learning Paths and Technological Capabilities: An Introductory Roadmap of Development Process", Economics of Technical Change and Innovation, forthcoming.

Cimoli, M., Porcile, G and Rovira, S. (2009) "Structural Change and the Balance-ofPayments Constraint: Why Latin America Failed to Converge?, Cambridge Journal of Economics, forthcoming.

Deb, P. (2008) Finite Mixture Models. Summer North American Stata User-s Group Meetings 2008.

Diaz-Alejandro, C. (1984) "Latin America in the 1930s", in: Thorpe, R. (Ed.), Latin America in the 1930s. Macmillan, London.

Dosi, G., Pavitt, K. \& Soete, L. The Econmics of Technical Change and International Trade, New York: Harvester Wheatsheaf, 1990.

Dutt, A. K. (2002) "Thirwall's Law and uneven development", Journal of Post Keynesian Economics, 24(3), 367-390.

ECLAC (2001) Una Década de Luces y Sombras: América Latina y el Caribe en los Años Noventa. Bogotá: Alfaomega.

ECLAC (2007) Progreso Técnico y Cambio Estructural en América Latina. Santiago: CEPAL-IDRC.

Fajnzylber, F. (1990) "Industrialización de América Latina: de la Caja Negra al Casillero Vacío", Cuadernos de la CEPAL 60, Santiago de Chile.

Fagerberg, J. (1988) "International Competitiveness", Economic Journal, 98, 355 -374.

Fagerberg, J. (1994) "Technology and International Differences in Growth rates", Journalof Economic Literature, 32, 1147- 1175.

Freeman, C. (1995) "The National System of Innovation in Historical Perspective",

Cambridge Journal of Economics, v. 19 (1), pp. 5-24.

Frühwirth-Schnatter, S. (2006) Finite Mixture and Markov Switching Models, New York: Springer.

Grossman, G. and Helpman, E. (1992) Innovation and Growth in the Global Economy. MIT Press.

Hausmann, R.; Hwang, J. and Rodrik, D. (2005)'What you Export Matters”, NBER Working Paper 11905, December.

Kaldor, N. (1978) Further Essays on Economic Theory. London: Duckworth.

León-Ledesma, M.A. (2002) "Accumulation, innovation and catching-up: an extended cumulative growth model”, Cambridge Journal of Economics, 26 (2), 201 - 216.

Lopez J. and Cruz, A. (2000) "Thirlwall's Law and Beyond: the Latin American Experience, Journal of Post Keynesian Economics, 22 (3), 477-95. 
Lundvall, B. (ed.) (1992) National systems of innovation: towards a theory of innovation and interactive learning, London: Pinter.

McCombie, J.S. (1989) "Thirwall's Law' and Balance of Payments Constrained Growth -A Comment on the Debate", Applied Economics, 18(11), 1215-25, November.

McCombie, J.S. (1997) "On the Empirics of Balance of Payments-Coinstrained Growth", Journal of Post Keynesian Economics, 19(3), 345-375.

McCombie, J. S. L.and Thirlwall A. P. (1994) Economic growth and the balance of payments constraint. New York: St. Martin's Press.

Miozzo, M. and V. Walsh (2006), International Competitiveness and Technological Change, Oxford, Oxford University Press.

Moreno-Brid, J.C. (2003) "Capital Flows, Interest Payments and the Balance-ofPayments Constrained Growth Model: a Theoretical and Empirical Analysis", Metroeconomica, 54(2), 346-365.

Narula, R. 2004. "Understanding Absorptive Capacities in an Innovation Systems Context: Consequences for Economic and Employment Growth", DRUID Working Paper no. 04-02, December.

Ocampo, J. A. (2005) "The quest for dynamic efficiency: structural dynamics and economic growth in developing countries", in Ocampo, J. A. (ed.), Beyond Reforms: Structural Dynamics and Macroeconomic Vulnerability, Stanford, ECLA-Stanford University Press.

Ocampo, J. A.; Rada, C. and Taylor, L. (2009) Growth and Policy in Developing Countries. New York: Columbia University Press.

Oliveira, F.H.P., Jayme, F.G. and Lemos, M.B. (2006) "Increasing Returns to Scale and International Diffusion of Technology: An Empirical Study for Brazil (19762000), World Development, 34 (1), p.75-88.

Pacheco López, P. and Thirwall, A. (2005) "Trade Liberalization, the Income Elasticity of Demand for Imports and Growth in Latin América", Department of Economics, University of Kent, Working paper, $\mathrm{N}^{\circ} 0505,2005$.

Pavitt, K (1984) "Sectoral patterns of technological change: towards a taxonomy and a theory", Research Policy, 13(6), pp. 343-75.

Porcile, G.; Dutra, M.V.; Meirelles, A. (2007) "Technology gap, real wages, and learning in a balance-of-payments---constrained growth model," Journal of Post Keynesian Economics, 29(3), pp. 473-500, May.

Prebisch, R. (1963) Hacia una Dinámica del Desarrollo Latinoamericano. México: Fondo de Cultura Económica.

Prebisch, R. (1981) Capitalismo periférico: crisis y transformación. México: Fondo de Cultura Económica.

Quah, D. (1996) "Twin peaks: growth and convergence in models of distribution dynamics", Economic Journal, 106, July, pp. 1045-1055.

Reinert, E. (1995) "Competitiveness and its predecessors--a 500-year cross-national perspective", Structural Change and Economic Dynamics, 6 (1), 23-42.

Rodríguez, O. (1980). La Teoria del Subdesarrollo de la Cepal. Mexico: Fondo de Cultura Económica

Rodríguez, O. (2007). El Estructuralismo Latinoamericano, México, Siglo XXI.

Rosenberg, N. (1982) Inside the black box: technology and economics. Cambridge: Cambridge University Press.

Schwarz, G. (1978) "Estimating the dimension of a model", Annals of Statistics 6.

Setterfield, M. and Cornwall, J. (2002) "A Neo-Kaldorian Perspective on the Rise and

Decline of the Golden Age", in M. Setterfield (ed.), The Economics of Demand-

Led Growth, Cheltenham, UK: Edward Elgar. 
Stallings, B. and Peres, W. (2000) Growth, Employment and Equity: The Impact of Economic Reforms in Latin América and the Caribbean. Washington: Brookings Institution Press.

Thirwall, A.P. (1979) "The balance of payments constrain as an explanation of international growth rates differences", Banca Nazionale del Lavoro Quarterly Review, 128(1), 45-53.

Thirwall, A. and Hussain, M. (1982) "The balance of payments constraint, capital flows and growth rates differences between developing countries", Oxford Economic Papers, 34 (3), 498-510.

Thirwall, A. (1997) "Reflections on the concept of balance-of-payments-constrained growth" Journal of Post Keynesian Economics, 19(3).

Thorpe, R. (1998) Progress, poverty and exclusion: An economic history of Latin America in the $20^{\text {th }}$ century. Washington, DC: Inter-Alerican Development Bank.

UNCTAD (2006) Bridging the Technology Gap Between and Within Nations", E/CN.16/2006/2, Geneva, March.

Verspagen (1993), B. Uneven Growth Between Interdependent Economies. Avebury: Aldershot.

Wooldrich, J. M. (2002). Econometric analysis of cross section and panel data. MIT Press. 


\section{FIGURES AND TABLES}

Figure 1. Technological Policy and the Elasticity Ratio: The Effect of a Rise in $\phi$

Figure 1A

Figure $1 B$

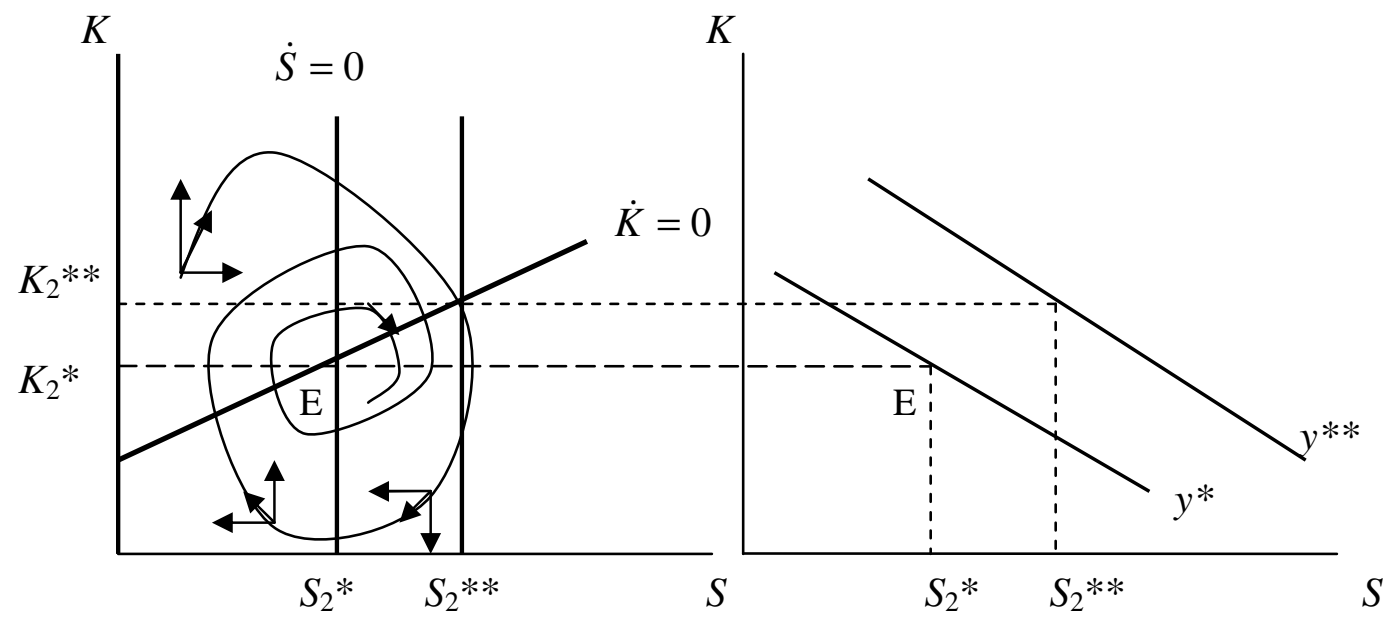


Table 1 - GDP Growth: Estimation Results, 1985-2007

\begin{tabular}{|c|c|c|c|}
\hline Coefficient & Pooled OLS & LSDV-FE & GLS-RE \\
\hline \multirow[t]{2}{*}{$\overline{\beta o}$} & $9,7098 * *$ & $8,0298 * *$ & $8,0181 * *$ \\
\hline & $(0,5312)$ & $(0,0935)$ & $(0,1334)$ \\
\hline \multirow[t]{2}{*}{$K$} & $0,0521 * *$ & $0,0280 * *$ & $0,0279 * *$ \\
\hline & $(0,0122)$ & $(0,0022)$ & $(0,0023)$ \\
\hline \multirow[t]{2}{*}{$S$} & $0,3738 * *$ & $0,0529 * *$ & $0,0573 * *$ \\
\hline & $(0,0138)$ & $(0,0065)$ & $(0,0065)$ \\
\hline \multirow[t]{2}{*}{$Z$} & $0,0657^{*}$ & $0,0234 * *$ & $0,0236 * *$ \\
\hline & $(0,0244)$ & $(0,0044)$ & $(0,0045)$ \\
\hline \multirow[t]{2}{*}{ Tot } & $-0,3794 * *$ & $-0,0810 * *$ & $-0,0802 * *$ \\
\hline & $(0,1132)$ & $(0,0200)$ & $(0,0202)$ \\
\hline$\overline{\mathbf{R}^{2}}$ & 0,35 & 0,35 & 0,35 \\
\hline $\mathbf{F}$ & 299,65 & 72,25 & - \\
\hline Wald $\chi^{2}$ & - & - & 297,88 \\
\hline \multicolumn{4}{|l|}{ Number of } \\
\hline
\end{tabular}

Source: Author's estimations based on TradeCAN and Penn World Table-mark 6 databases. Note: S, share of high-tech sectors in total exports; $K$, share of sectors with higher demand growth than the world average; $z$, growth rate of the world economy; tot, terms of trade. Dependent variable: GDP growth, $y$. Standard deviations between brackets; $(* *)$ and $(*)$ indicate that the coefficient is significant at the $1 \%$ level and $5 \%$ levels, respectively. 
Table 2 - GDP Growth: Estimation Results, Different Periods

\begin{tabular}{|c|c|c|c|c|}
\hline Coefficient & 1985-1990 & 1991-1995 & 1996-2000 & 2001-2007 \\
\hline \multirow[t]{2}{*}{$\beta o$} & 8,1886 ** & $8,0872 * *$ & $8,7709 * *$ & $8,0516^{* *}$ \\
\hline & $(0,1086)$ & $(0,1744)$ & $(0,1311)$ & $(0,1089)$ \\
\hline \multirow[t]{2}{*}{$\boldsymbol{K}$} & $-0,0058 * *$ & n.s. & $0,0135 * *$ & $0,0041 * *$ \\
\hline & $(0,0020)$ & n.s. & $(0,0036)$ & $(0,0005)$ \\
\hline \multirow[t]{2}{*}{$S$} & $0,0211 * *$ & $0,0104 * *$ & $0,0110 * *$ & $0,0108 *$ \\
\hline & $(0,0009)$ & $(0,0044)$ & $(0,0074)$ & $(0,0058)$ \\
\hline \multirow[t]{2}{*}{$Z$} & $0,0078 *$ & $0,0143 * *$ & $0,0098 * *$ & $0,0450 * *$ \\
\hline & $(0,0045)$ & $(0,0049)$ & $(0,0040)$ & $(0,0033)$ \\
\hline \multirow[t]{2}{*}{ Tot } & $0,0626 *$ & $-0,0856^{*}$ & $-0,0529 *$ & $-0,1042 * *$ \\
\hline & $(0,0229)$ & $(0,0376)$ & $(0,0277)$ & $(0,0229)$ \\
\hline $\mathbf{R}^{2}$ & 0,19 & 0,11 & 0,21 & 0,23 \\
\hline $\mathbf{F}$ & 24,89 & 13,63 & 17,87 & 67,18 \\
\hline Obs & 505 & 432 & 448 & 681 \\
\hline
\end{tabular}

Source: Author's estimations based on TradeCAN and Penn World Table-mark 6 databases. Note: S, share of high-tech sectors in total exports; $K$, share of sectors with higher demand growth than the world average; $z$, growth rate of the world economy; tot, terms of trade. Dependent variable: GDP growth, $y$. Standard deviations between brackets; $(* *)$ and $(*)$ indicate that the coefficient is significant at the $1 \%$ level and $5 \%$ levels, respectively. 
Table 3 - The Number of Components in the Model: AIC and BIC

\begin{tabular}{lll}
\hline \multicolumn{1}{c}{ Model } & AIC & BIC \\
\hline OLS one component & 5673,10 & 5701,27 \\
FMM two components & 5185,61 & 5269,50 \\
FMM three components & 5118,86 & 5247,50 \\
\hline
\end{tabular}

Source: Author's estimations

Table 4 - Groups in the sample: Results from FMM

\begin{tabular}{lrrr}
\hline Variables and statistics & Group 1 & Group 2 & Group 3 \\
\hline Average GDP per capita & 4064,71 & 7753,39 & 19214,07 \\
\% of countries in the sample & $55 \%$ & $31 \%$ & $14 \%$ \\
Wald $\chi^{2}$ & & - & 3754,10 \\
AIC & & - & 5118,86 \\
BIC & & - & 5247,50 \\
\hline Obs & & & 2066 \\
\hline
\end{tabular}

Source: Author's estimations 
Table 5 - GDP Growth: Finite Mixture Regression Results, 1985-2007

\section{Grupo 1 Grupo 2 Grupo 3}

$\begin{array}{lrrr}\text { Bo } & 10,3393^{* *} & 5,1445^{* *} & 13,5893^{* *} \\ & (0,5262) & (0,3622) & (0,4250) \\ \boldsymbol{K} & 0,0445^{* *} & 0,0645^{*} & 0,0710^{* *} \\ & (0,0140) & (0,0140) & (0,0129) \\ \mathbf{S} & 0,2752^{* *} & 0,6272^{* *} & 0,1657 * * \\ & (0,0170) & (0,0153) & (0,0134) \\ \mathbf{Z} & 0,0618^{*} & \text { n.s. } & 0,0709^{* *} \\ & (0,0298) & \text { n.s. } & (0,0157) \\ & -0,5575^{* *} & -0,7498 * * & 0,9041^{*} \\ \text { Lag } & (0,1128) & (0,0713) & (0,0919) \\ & 0,2195^{* *} & 0,2997 * * & 0,7103 * * \\ & 0,0478 & (0,0228) & (0,0755)\end{array}$

Source: Author's estimations based on TradeCAN and Penn World Table-mark 6 databases. Note: S, share of high-tech sectors in total exports; $K$, share of sectors with higher demand growth than the world average; $z$, growth rate of the world economy; tot, terms of trade. Dependent variable: GDP growth, $y$. Standard deviations between brackets; $(* *)$ and $(*)$ indicate that the coefficient is significant at the $1 \%$ level and $5 \%$ levels, respectively. 
Statistical Appendix

Table A1: Countries and Variables: Averages, 1985-2007

\begin{tabular}{|c|c|c|c|}
\hline Country & $S$ & $K$ & GDP growth \\
\hline \multicolumn{4}{|l|}{ Industrialized } \\
\hline USA & 28,52 & 14,91 & 2,03 \\
\hline Finland & 17,52 & 12,16 & 2,34 \\
\hline Sweden & 17,70 & 14,22 & 2,09 \\
\hline Canada & 9,15 & 15,55 & 2,08 \\
\hline Australia & 4,38 & 14,12 & 2,38 \\
\hline Norway & 4,27 & 16,77 & 2,64 \\
\hline Japan & 29,58 & 15,19 & 1,87 \\
\hline UK & 22,54 & 16,21 & 2,60 \\
\hline Holland & 16,48 & 15,01 & 2,18 \\
\hline Germany & 15,24 & 12,94 & 1,85 \\
\hline Israel & 20,08 & 13,69 & 2,09 \\
\hline Belgium & 8,88 & 13,55 & 2,27 \\
\hline Nova Zealand & 2,60 & 8,66 & 1,70 \\
\hline Austria & 12,05 & 12,53 & 2,22 \\
\hline France & 18,82 & 14,40 & 1,72 \\
\hline Ireland & 33,19 & 19,84 & 4,98 \\
\hline Spain & 8,92 & 12,85 & 3,34 \\
\hline Italy & 9,80 & 13,10 & 1,80 \\
\hline Portugal & 6,71 & 12,70 & 2,89 \\
\hline Greece & 4,59 & 13,63 & 2,45 \\
\hline \begin{tabular}{|l|} 
Average \\
\end{tabular} & 14,21 & 14,10 & 2,37 \\
\hline \multicolumn{4}{|l|}{ Developing Asia } \\
\hline Korea & 30,62 & 10,13 & 5,55 \\
\hline Singapore & 50,81 & 20,69 & 4,42 \\
\hline Malaysia & 40,54 & 18,10 & 4,78 \\
\hline Thailand & 26,14 & 16,12 & 4,48 \\
\hline Filipinas & 46,60 & 15,42 & 1.62 \\
\hline China & 17,34 & 12.38 & 8,61 \\
\hline India & 3,66 & 11,69 & 3,89 \\
\hline Sri Lanka & 2,51 & 10,69 & 8,28 \\
\hline Indonesia & 5,50 & 14,56 & 3,31 \\
\hline Average & 24,86 & 14,42 & 4,49 \\
\hline
\end{tabular}




\begin{tabular}{|l|cc|c|}
\hline Latin America & $\boldsymbol{S}$ & $\boldsymbol{K}$ & GDP growth \\
Argentina & 2,25 & 13,59 & 1,48 \\
Chile & 0,53 & 13,61 & 4,45 \\
Costa Rica & 18,88 & 12,90 & 2,20 \\
Mexico & 19,53 & 15,02 & 1,16 \\
Brazil & 5,54 & 12,66 & 1,14 \\
Peru & 0,50 & 13,39 & 1,37 \\
Bolivia & 0,36 & 17,82 & 1,09 \\
Ecuador & 0,65 & 15,14 & 0,71 \\
Nicaragua & 0,78 & 10,74 & $-1,72$ \\
\hline Average & $\mathbf{5 , 4 4}$ & $\mathbf{1 3 , 8 7}$ & $\mathbf{1 , 3 2}$ \\
\hline
\end{tabular}

Sources: Specialization patterns elaborated from data provided by TradeCAN (2009); rates of economic growth are from the World Penn Table 6.2 (2009).

Key for the variables

$S$ : share of high tech exports in total exports, average 1985-2007

$K$ : share of exports which grow at higher rates than the world average in total exports, average 1985-2007 GDP growth, 1985-2007 
Table A2. Groups of Countries According With FMM, 1985

\begin{tabular}{|l|c|c|c|}
\hline \multicolumn{1}{|c|}{ Country } & Group 1 & Group 2 & Group 3 \\
\hline Albania & & $*$ & \\
\hline Algeria & & $*$ & \\
\hline Argentina & & $*$ & \\
\hline Australia & & & $*$ \\
\hline Austria & & & $*$ \\
\hline Bangladesh & $*$ & & \\
\hline Belgium & $*$ & & \\
\hline Benin & $*$ & & \\
\hline Bolivia & & $*$ & \\
\hline Brazil & & $*$ & \\
\hline Bulgaria & $*$ & & \\
\hline Burkina Faso & & $*(1)$ & \\
\hline Cameroon & $*$ & & \\
\hline Canada & $*$ & & \\
\hline $\begin{array}{l}\text { Central African } \\
\text { Republic }\end{array}$ & $*$ & & \\
\hline Chile & & & \\
\hline China & & & \\
\hline Colombia & & & \\
\hline Congo, Dem Rep & $*$ & & \\
\hline Costa Rica & & & \\
\hline Cote d'Ivore & & & \\
\hline Denmark & & & \\
\hline Dominican Republic & & & \\
\hline Ecuador & & & \\
\hline Egypt & & & \\
\hline El Salvador & & & \\
\hline Ethiopia & & & \\
\hline Finland & & & \\
\hline France & & & \\
\hline Gabon & & & \\
\hline Gambia & & & \\
\hline Germany & & & \\
\hline Ghana & & & \\
\hline Greece & & & \\
\hline Guatemala & & & \\
\hline Guinea & & \\
\hline Guinea-Bissau & & & \\
\hline Haiti & & & \\
\hline Honduras & & & \\
\hline Hong Kong & & & \\
\hline Hungary & & & \\
\hline India & & & \\
\hline Indonesia & & & \\
\hline
\end{tabular}




\begin{tabular}{|c|c|c|c|}
\hline Iran & & * & \\
\hline Ireland & & ${ }^{*}(3)$ & \\
\hline Israel & & & * \\
\hline Italy & & & * \\
\hline Jamaica & & * & \\
\hline Japan & & & * \\
\hline Jordan & & * & \\
\hline Kenya & * & & \\
\hline Korea, Rep. & & *(3) & \\
\hline Lao & * & & \\
\hline Madagascar & * & & \\
\hline Malawi & * & & \\
\hline Malaysia & & * & \\
\hline Mali & * & & \\
\hline Mauritania & * & & \\
\hline Mauritius & & *(3) & \\
\hline Mexico & & * & \\
\hline Mongolia & * & & \\
\hline Morocco & & * & \\
\hline Mozambique & * & & \\
\hline Nepal & * & & \\
\hline Netherlands & & & * \\
\hline New Zeland & & & * \\
\hline Nicaragua & & * & \\
\hline Niger & * & & \\
\hline Nigeria & * & & \\
\hline Norway & & & * \\
\hline Oman & & *(3) & \\
\hline Pakistan & * & & \\
\hline Panama & & * & \\
\hline Papau New Guinea & & * & \\
\hline Paraguay & & * & \\
\hline Peru & & * & \\
\hline Philipines & ${ }^{*}(2)$ & & \\
\hline Poland & & * & \\
\hline Portugal & & *(3) & \\
\hline Romania & & * & \\
\hline Rwanda & * & & \\
\hline Senegal & * & & \\
\hline Sierra Leone & * & & \\
\hline Singapore & & *(3) & \\
\hline Spain & & *(3) & \\
\hline Sri Lanka & ${ }^{*}(2)$ & & \\
\hline Sudan & * & & \\
\hline Sweden & & & * \\
\hline Switzerland & & & * \\
\hline Syrian Arab Republic & * & & \\
\hline
\end{tabular}




\begin{tabular}{|l|c|c|c|} 
Tanzania & $*$ & & \\
\hline Thailand & & $*$ & \\
\hline Togo & $*$ & & \\
\hline Trinidad and Tobago & & $*$ & \\
\hline Tunisia & & $*$ & \\
\hline Turkey & & $*$ & \\
\hline Uganda & & & \\
\hline United Kingdom & & & $*$ \\
\hline United States & & $*$ & \\
\hline Uruguay & & $*$ & \\
\hline Venezuela & $*$ & & \\
\hline Vietnam & $*$ & & \\
\hline Zambia & $*$ & & \\
\hline Zimbabwe &
\end{tabular}

Source: Author's estimations based on Penn World Table-mark 6 databases.

Note: the star indicates to which Group the country belonged in 1985. The number between brackets indicates towards which group the country migrated in 2003 (when a change of Group occurred in the period). 


\section{Endnotes}

${ }^{1}$ Structuralist views can be found in Prebisch (1953 and 1981) and Fajnzylber (1990). See also Rodriguez (1977, 1980, 2007), ECLAC (2007), Cimoli and Porcile, (2009) and Ocampo et al (2009).

${ }^{2}$ For a critical appraisal of the prevailing neoclassical view see Reinert (1995). An alternative view framed within the mainstream tradition can be found in Grossman and Helpman (1992) and Hausmann el al (2005).

${ }^{3}$ There is already a large literature on the empirics of BOP-constrained growth models. Examples are McCombie (1989), Alonso and Gracimartín (1998-99), Lopez and Cruz (2000), Bértola et al (2002), Pacheco-Lopez and Thirlwall (2005) and Cimoli, et al (2009).

${ }^{4}$ Thirlwall's Law is an important result of Keynesian growth models in open economies which has been extensively discussed in the literature. For this reason we will not present the derivation of equation (1) in this paper. The reader may find a detailed discussion of the basic model in McCombie and Thirlwall (1994, chapter 3). See also Dutt (2002), Stterfield (2002) and Setterfield and Cornwall (2002) for extensions of the Keynesian growth models.

${ }^{5}$ Periods in which the external debt rises should be followed by periods in which the debt is paid, in such a way that on average net capital flows must be close to zero. BOPconstrained-growth models with capital flows have been suggested by Thirlwall and Hussein (1982), Moreno-Brid (2003).

${ }^{6}$ Several mechanisms work to adjust the effective growth rate to the equilibrium growth rate $y^{*}$. External disequilibrium leads to constraints on imports of foreign capital goods, rises in interest rates to attract foreign lending, and higher uncertainty and loss of confidence in the growth prospects of the economy.

${ }^{7}$ The expression "commodity lottery" was first proposed by Díaz Alejandro (1984).

8 Argentina, for instance, was very successful until the 1930s based on exports of primary goods to the British market, but it was unable to adapt to the new international conditions that emerged out of the end of the British hegemony in the international system (Bértola and Porcile, 2006). The Latin American economic history shows a persistent trend of divergence which is related to its continuous dependence on exports 
of low-tech goods, intensive in natural resources and / or unskilled labor (Ocampo et al, 2009).

${ }^{9}$ The Schumpeterian and structuralist traditions sustain that the pattern of specialization largely responds to international asymmetries in technological capabilities. Several works have linked the technology gap to competitiveness and growth -- see for instance Fagerberg (1988), Amable (2000), Castellacci (2002), León-Ledesma (2002) and Oliveira et al (2006).

${ }^{10}$ Cf. UNCTAD (2006) for a detailed discussion of this point

11 This autonomous component can be seen as the result of different levels of autonomous investment in technology in North and South. Since the North invests more than the South, $a>0$.

$12 \lambda$ expresses the capacity of the country to transform opportunities for imitation into effective learning and catching up.

${ }^{13}$ For a definition of NSI see Lundvall (1992) and Freeman (1995). A discussion of this topic in developing economies is presented in Cimoli and Porcile (2009) and Albuquerque (2007).

14 Some industries innovate at higher rates than others, produce complementary knowledge to innovative firms or play a significant role in diffusing innovations to the rest of the economy, which strongly affects international competitiveness. The classical work is Pavitt (1984).

15 The 107 countries included in the estimations are presented in a statistical appendix, Table A.1. Raw data obtained from the TradeCan2009, WTO, WDI and Penn World Table 6.3 database available on request.

${ }^{16}$ This is the reason why we estimated equation (5) rather than equation (6).

17 The methodology allows for assuming different probability distributions for the error term (Normal or Gaussian, Poisson, Gama, Negative Binomial, Student,and Weibull). In our model we assumed a normal distribution.

${ }^{18}$ See Akaike (1973) and Schwarz (1978). 